\title{
Sensitization of estrogen receptor-positive breast cancer cell lines to 4-hydroxytamoxifen by isothiocyanates present in cruciferous plants
}

\author{
Anna Pawlik $^{1}$ - Monika Słomińska-Wojewódzka ${ }^{1}$ Anna Herman-Antosiewicz ${ }^{1}$
}

Received: 3 February 2015 / Accepted: 14 May 2015 / Published online: 27 May 2015

(C) The Author(s) 2015. This article is published with open access at Springerlink.com

\begin{abstract}
Purpose Tamoxifen has been used for the treatment of estrogen receptor (ER)-positive breast cancers and in women who are at an increased risk of breast cancer. Acquired resistance to this drug and its toxicity still pose a clinically significant problem, especially in the prevention setting. Isothiocyanates present in cruciferous plants, such as sulforaphane or erucin, have been shown to reduce growth of breast cancer cells in vivo and in vitro. In this study, we explored their ability to sensitize cancer cells to 4-hydroxytamoxifen.

Methods We used three ER-positive breast cancer cell lines, T47D, MCF-7 and BT-474, as well as the drug-resistant T47D and MCF-7 derivatives. We examined the effect of 4-hydroxytamoxifen, isothiocyanates and their combinations on cell viability by MTT and clonogenic assays. Impact of treatments on the levels of proteins engaged in apoptosis and autophagy was determined by Western blotting.

Results Isothiocyanates act in a synergistic way with 4-hydroxytamoxifen, and co-treatment reduces breast cancer cell viability and clonogenic potential more effectively than treatment with any single agent. This is connected with a drop in the Bcl-2/Bax ratio and the level of survivin as well as increased PARP cleavage, and elevation in ADRP, the mitochondrial stress marker. Moreover, isothiocyanates sensitize 4-hydroxytamoxifen-resistant T47D and MCF-7 cells to the drug.
\end{abstract}

Anna Herman-Antosiewicz

anna.herman-antosiewicz@biol.ug.edu.pl

1 Department of Molecular Biology, University of Gdańsk, Wita Stwosza 59, 80-308 Gdańsk, Poland
Conclusion Isothiocyanates enhance response to 4-hydroxytamoxifen, which allows for reduction of the effective drug concentration. Combinatorial strategy may hold promise in development of therapies and chemoprevention strategies against ER-positive breast tumors, even those with acquired resistance to the drug.

Keywords Breast cancer - Sulforaphane - Erucin · 4-Hydroxytamoxifen · Estrogen receptor

\section{Introduction}

Breast cancer is the leading cause of cancer-related deaths in women [27]. Estrogen receptor (ER)-positive breast tumors comprise approximately $75 \%$ of the breast cancer cases [6]. Tamoxifen is a drug conventionally used in prevention and treatment of advanced estrogen receptor-positive breast cancer in pre- and postmenopausal women [13, 58]. Tamoxifen and its active metabolite, 4-hydroxytamoxifen, act as an estrogen antagonist or agonist, depending on tissue and organ type. The ER, a regulator of expression of genes involved in the ER-positive tumor progression, is able to stimulate cancer growth in two different ways: a classical way by binding to its responsive elements in a given gene's promoter, and nongenomic through activation of growth factor receptors and cellular pro-survival kinases [8, 43]. 4-Hydroxytamoxifen demonstrates estrogen antagonist activity in breast cells. All ER antagonists display the same crucial mechanism of action: They bind ER and block its activity [17, 28]. However, many breast cancer cells show a primary or secondary endocrine resistance. Statistics indicates that in 30-50\% of women with ER-positive breast cancer, de novo or intrinsic resistance to tamoxifen occurs and in many patients tumor recurrence is observed 
after drug therapy. Different molecular mechanisms may lead to a development of cellular resistance to the hormone therapy and protect cancer cells from death induced by drugs. Among them, the loss of ER or alteration in its structure and function, overactivation of serine/threonine protein kinase B (Akt), alteration in the ER signal transduction, and crosstalk between the ER and growth factor receptors have been reported [50, 51]. Moreover, long-term administration of the selective ER modulator may lead to serious side effects, such as menopausal symptoms, venous thromboembolic events, endometrial hyperplasia, polyps and cancer or ovarian cysts [41, 42].

Isothiocyanates (ITC) are naturally occurring phytochemicals present in cruciferous plants. Sulforaphane [1-isothiocyanato-4-(methylsulfinyl)-butane), SFN] and its reduced analog, erucin [1-isothiocyanato-4-(methylthio)butane, ERN], exhibit chemopreventive and antitumor activities against different types of cancers. The molecular mechanisms of SFN action include inhibition of phase I carcinogen-activating enzymes, induction of phase II carcinogen detoxification enzymes, and induction of the cell cycle arrest and apoptosis. Preventive activity of SFN has been reported in numerous in vivo models. Administration of SFN by oral gavage inhibited development of mammary tumors in female Sprague-Dawley rats treated with the 9,10-dimethyl-1,2-benzanthracene (DMBA) carcinogen [65] or prostate carcinogenesis and pulmonary metastasis in TRAMP mice [57]. Feeding A/J mice with SFN and its $\mathrm{N}$-acetylcysteine conjugate resulted in an inhibition of malignant progression of lung adenomas induced by the tobacco carcinogens [15]. Sulforaphane protected male Syrian hamsters treated with the pancreatic carcinogen, $\mathrm{N}$-nitroso-bis(2-oxopropyl)amine, against the development of a pancreatic tumor [35]. These observations were supported by in vitro studies, showing that SFN induces apoptosis, for instance, in PC-3 prostate cancer cells [56], MDA-MB-231, MDA-MB-468, MCF-7 and T47D human breast cancer cell lines [49], UM-UC-3 bladder tumor cells [59], A549 nonsmall lung cancer cells [40] and HT29 colon cancer cell lines [19]. SFN has been also shown to inhibit cell cycle progression of different cancer cells, including PC-3 prostate cancer cells [55], HT29 human colon cancer cells [48, 53], PaCa-2 and PANC-1 pancreatic cancer cells [48] or MCF-7 breast cancer cells [24]. In addition, it has been shown that SFN induces autophagy [22, 31]. In the case of cells with the defective apoptosis, autophagy may lead to the type II programmed cell death. In some conditions, however, it may suppress or delay cell death, such as in the case of prostate or breast cancer cells treated with SFN $[22,31]$.

Erucin is abundant in salad rocket and can be generated by interconversion of SFN. It has been reported that erucin also modulates phase I enzymes [37] and phase II enzymes [26], induces pro-apoptotic signals and influences cell cycle progression, for instance, in human leukemia cells [25], HepG2 human hepatocellular carcinoma cells [36], human lung carcinoma A549 cells [39], bladder J82, UM-UC-3 cancer cells [1] and more recently-in MCF-7 breast cancer cells [5].

On the basis of the data described above as well as recently reported results showing that SFN inhibits pro-survival Akt-mTOR-S6K pathway in phenotypically different breast cancer cells [45], we hypothesize that application of ITC may enhance anti-proliferative activity of 4-hydroxytamoxifen. In the present study, we used three ER-positive breast cancer cell lines, T47D, MCF-7 and BT-474, as well as drug-resistant derivatives of T47D and MCF-7 cells, to compare their sensitivity to structurally related ITC (sulforaphane and erucin) as well as 4-hydroxytamoxifen, and test whether these naturally occurring phytochemicals sensitize ER-positive breast cancer cells to the drug.

\section{Materials and methods}

\section{Reagents}

R,S-sulforaphane (purity $\geq 98 \%$ ) and erucin (purity $\geq 98 \%$ ) were obtained from LKT Laboratories (St. Paul, MN). They were prepared in DMSO and stored at a stock concentration of $10 \mathrm{mM}$ at $-20{ }^{\circ} \mathrm{C}$. RPMI- 1640 medium, fetal bovine serum was purchased from Life Technologies (Grand Island, NY). (Z)-4-hydroxytamoxifen (purity $\geq 98 \%$ ), penicillin-streptomycin solution, DMSO, sulforhodamine B, 3-(4,5-dimethylthiazol-2-yl)-2,5-diphenyltetrazolium bromide (MTT), anti-rabbit and anti- $\beta$-actin antibodies conjugated with HPR were from Sigma-Aldrich (St. Louis, MO). (Z)-4-hydroxytamoxifen (purity $\geq 98 \%$ ) was dissolved in ethanol at a concentration of $10 \mathrm{mM}$ and stored at $4{ }^{\circ} \mathrm{C}$. Antibodies against Bcl-2, Bax, survivin and ADRP were from Santa Cruz Biotechnology (Santa Cruz, CA), antibody against PARP was from Cell Signaling Technology (Danvers, MA) and anti-LC3 antibody was purchased from Medical and Biological Laboratories Co., Ltd. (Woburn, MA).

\section{Cell culture and treatment}

ER-positive breast cancer cell lines, MCF-7, T47D and BT-474, were cultured in RPMI-1640 supplemented with $10 \%$ fetal bovine serum and $1 \%$ penicillin/streptomycin solution. Tamoxifen-resistant derivatives of MCF-7 and T47D cells were obtained by continuous exposure of parental cell lines to increasing concentrations of 4-hydroxytamoxifen for over 15 months. Cells were cultured in RPMI medium without phenol red, with $10 \%$ charcoal 
stripped-fetal bovine serum. For the first 3 months, parental cells were continuously treated with $100 \mathrm{nM}$ 4-hydroxytamoxifen. After this time, the concentration of the drug was increased to $500 \mathrm{nM}$. The medium with the appropriate concentration of 4-hydroxytamoxifen was changed every 4 days. ER-negative breast cancer cell line, MDA-MB-231, was maintained in MEM supplemented with $10 \%$ FBS, $1 \mathrm{mM}$ sodium pyruvate, nonessential amino acids and antibiotics. Each cell line was incubated at $37{ }^{\circ} \mathrm{C}$ in $5 \% \mathrm{CO}_{2}$. Twenty four hours after plating, cells were treated with the desired concentration of isothiocyanate with or without (Z)-4-hydroxytamoxifen or an equivalent volume of ethanol and/or DMSO (vehicle control) for $96 \mathrm{~h}$ with medium replacement after $48 \mathrm{~h}$.

\section{Cell viability assay}

Cells were seeded at density $2 \times 10^{3}$ cells per well in 96-well plate and allowed to grow for $24 \mathrm{~h}$. After that time cells were treated with increasing concentrations of ITC $(2.5-50 \mu \mathrm{M})$, increasing concentrations of 4-hydroxytamoxifen $(0.05-10 \mu \mathrm{M})$ or combinations of both. Control samples were treated with DMSO, ethanol or DMSO and ethanol at appropriate concentrations. After $48 \mathrm{~h}$, medium was replaced with the fresh medium containing the same supplements. After $96 \mathrm{~h}$ of treatment, $25 \mu \mathrm{l}$ of MTT (3-(4,5-dimethylthiazol-2-yl)-2,5-diphenyltetrazolium bromide) stock solution $(4 \mathrm{mg} / \mathrm{ml}$ in PBS) was added to each well for $4 \mathrm{~h}$. Next, the formazan crystals were dissolved in $100 \%$ DMSO, and absorbance was measured at $570 \mathrm{~nm}$ with a reference filter of $660 \mathrm{~nm}$ in Victor3 microplate reader (PerkinElmer Life and Analytical Sciences, Boston, MA). To inhibit autophagy induction, cells were pretreated with $50 \mathrm{nM}$ wortmannin and then treated with ITC and 4-hydroxytamoxifen as described above. After 96 h, $100 \mu 1$ of $10 \%$ (w/v) aqueous solution of ice-cold trichloroacetic acid was added for $1 \mathrm{~h}$. Plates were washed with water, allowed to airdry and stained with $100 \mu 1$ of $0.4 \%$ sulforhodamine B solution in $1 \%$ acetic acid for $15 \mathrm{~min}$. Cells were washed 5 times with $1 \%$ acetic acid and dried. After addition of $10 \mathrm{mM}$ Tris base (pH 10.5, $150 \mu \mathrm{l} /$ well), the absorbance was measured at $570 \mathrm{~nm}$ using Victor3 microplate reader. Data were obtained from at least three independent experiments, and each treatment condition assayed in triplicate.

\section{Clonogenic assay}

Cells were plated at density $5 \times 10^{4}$ per $100 \mathrm{~mm}$ plate. After $24 \mathrm{~h}$, cells were treated with $0.5 \mu \mathrm{M}$ 4-hydroxytamoxifen, ITC or combinations of these chemicals. Control samples were treated with ethanol and/or DMSO at appropriate concentration for 8 days, and every 2 days the medium was changed to the fresh one with the same supplements. After 8 days of treatment, cells were trypsinized and plated at 800 per $100 \mathrm{~mm}$ plate in duplicate. Colonies were stained with crystal violet $(0.5 \% \mathrm{w} / \mathrm{v})$ and counted 2 weeks (in case of T47D and MCF-7 cell lines) or 4 weeks (in case of BT-474 cells) after plating. The experiment was repeated twice.

\section{Western blot analysis}

MCF-7 and T47D cells were plated at density $2.5 \times 10^{5}$ and BT-474 at density $5 \times 10^{5}$ per $100 \mathrm{~mm}$ plate. Cells were treated as described in the "Cell culture and treatment" section. Control samples were treated with ethanol and/or DMSO at appropriate concentrations. After $48 \mathrm{~h}$, medium was changed to fresh one and the compounds were added again. After $96 \mathrm{~h}$, cells were lysed in a solution containing $50 \mathrm{mM}$ Tris (pH 7.5), $1 \%$ Triton X-100, $150 \mathrm{mM}$ $\mathrm{NaCl}, 0.5 \mathrm{mM}$ EDTA, protease and phosphatase inhibitor cocktails (Roche Diagnostics, Germany) and centrifuged at $13,000 \mathrm{rpm}$ at $4{ }^{\circ} \mathrm{C}$ for $30 \mathrm{~min}$. Immunoblots were performed as previously described [45].

\section{Statistical analysis and analysis of synergy}

Data were analyzed using GraphPad Prism software. Oneway ANOVA followed by Bonferroni's multiple comparison test was used to determine statistical significance of differences in the measured variables. Differences were considered significant at $p<0.05$.

Data from MTT viability assay were analyzed using the method of Chou and Talalay [11] and CompuSyn software to determine the dose that gives the median effect, linear correlation coefficient in case of treatment with a single compound, and combination index (CI) for samples treated with two compounds. The $\mathrm{CI}$ is a quantitative measure of the degree of interaction between drugs. $\mathrm{CI}<1, \mathrm{CI}=1$ and $\mathrm{CI}>1$ denote synergism, additivity and antagonism, respectively. Variable ratios of ITC and 4-hydroxytamoxifen were used.

\section{Results}

Effect of ITC, 4-hydroxytamoxifen or their combinations on survival of ER-positive breast cancer cell lines

We investigated the effect of sulforaphane, erucin and 4-hydroxytamoxifen alone or in combinations on viability of three ER-positive breast cancer cell lines: MCF-7, T47D and BT-474. Both ITC inhibited cell growth in a 
dose-dependent manner (Fig. 1). T47D and MCF-7 cells were similarly sensitive to sulforaphane $\left(\mathrm{IC}_{50}\right.$ were 6.6 and $5 \mu \mathrm{M}$, respectively) and to erucin $\left(\mathrm{IC}_{50}=7.6\right.$ and $9.7 \mu \mathrm{M}$, respectively). Interestingly, marked differences in sensitivity of BT-474 cell line to sulforaphane and erucin were observed with $\mathrm{IC}_{50}$ values of 15 or $19.7 \mu \mathrm{M}$, respectively (Fig. 1a, b). Sensitivity of T47D, MCF-7 and BT-474 cell lines to 4-hydroxytamoxifen was dependent of its dose, and $\mathrm{IC}_{50}$ values after $96 \mathrm{~h}$ of treatment were 4.2, 3.2 and $5.7 \mu \mathrm{M}$, respectively (Fig. 1c).

Next, we assessed viability of three breast cancer cell lines after co-treatment with ITC at concentrations equal or lower than their respective $\mathrm{IC}_{50}$ value $(5 \mu \mathrm{M})$ and 4-hydroxytamoxifen at a concentration close to its $\mathrm{IC}_{20}(0.5$
Fig. 1 Dose-dependent effect of SFN (a), ERN (b) or 4-hydroxytamoxifen (c) on survival of T47D, MCF-7 and BT-474 cell lines after $96 \mathrm{~h}$ of treatment. Control samples were treated with appropriate concentrations of DMSO. Viability was assayed by MTT method as described in "Materials and methods". Results shown are mean \pm SE of three independent experiments performed in triplicate
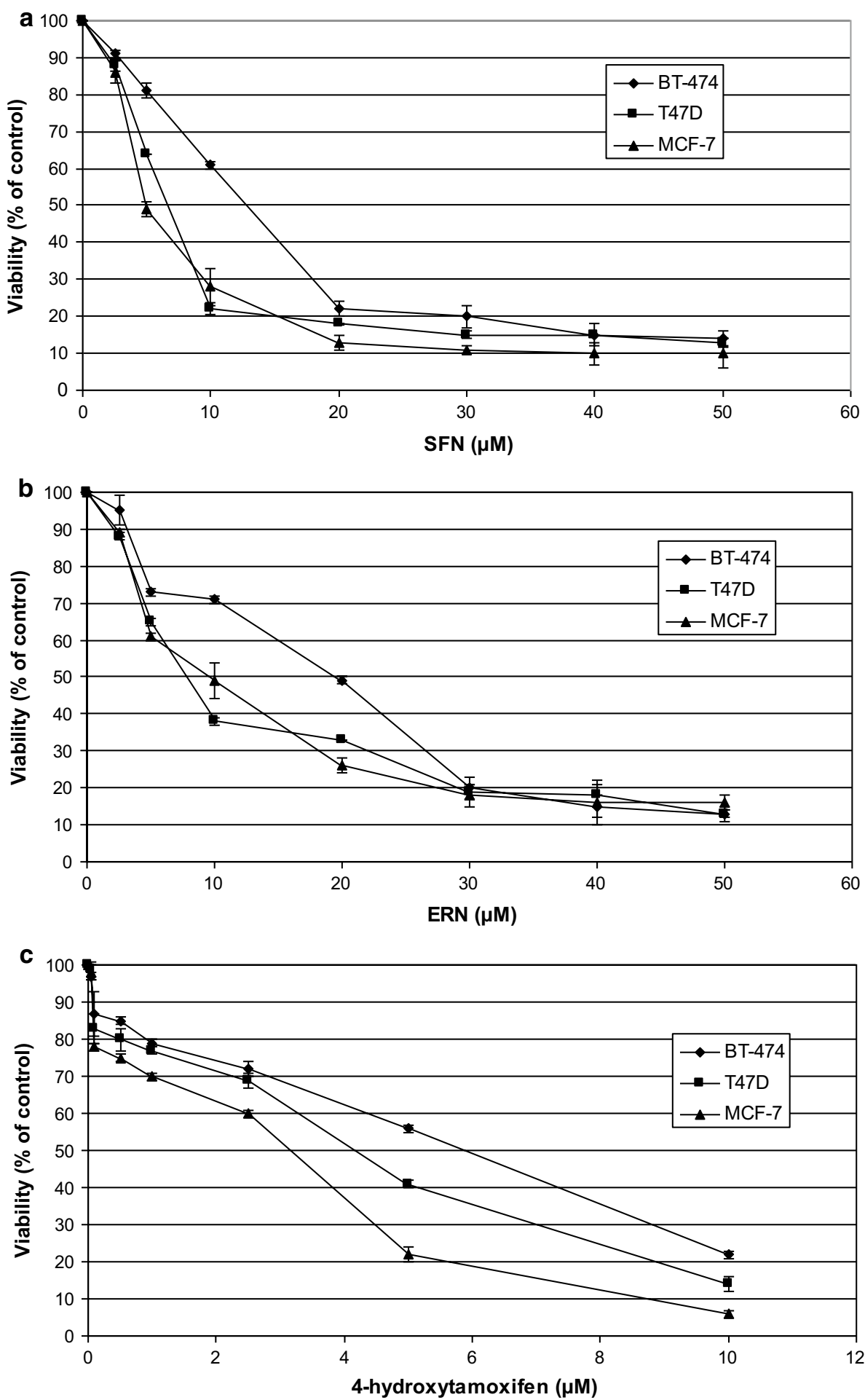
or $1 \mu \mathrm{M})$. The results obtained showed that combination of ITC and 4-hydroxytamoxifen inhibited cell viability more efficiently than either compound used alone: It was about $20 \%$ lower upon combined treatment than viability of cells treated with ITC and about 30-50 \% lower than viability of cells treated with 4-hydroxytamoxifen only (Figs. 2, 3). To elucidate whether the greater effect of combined treatment
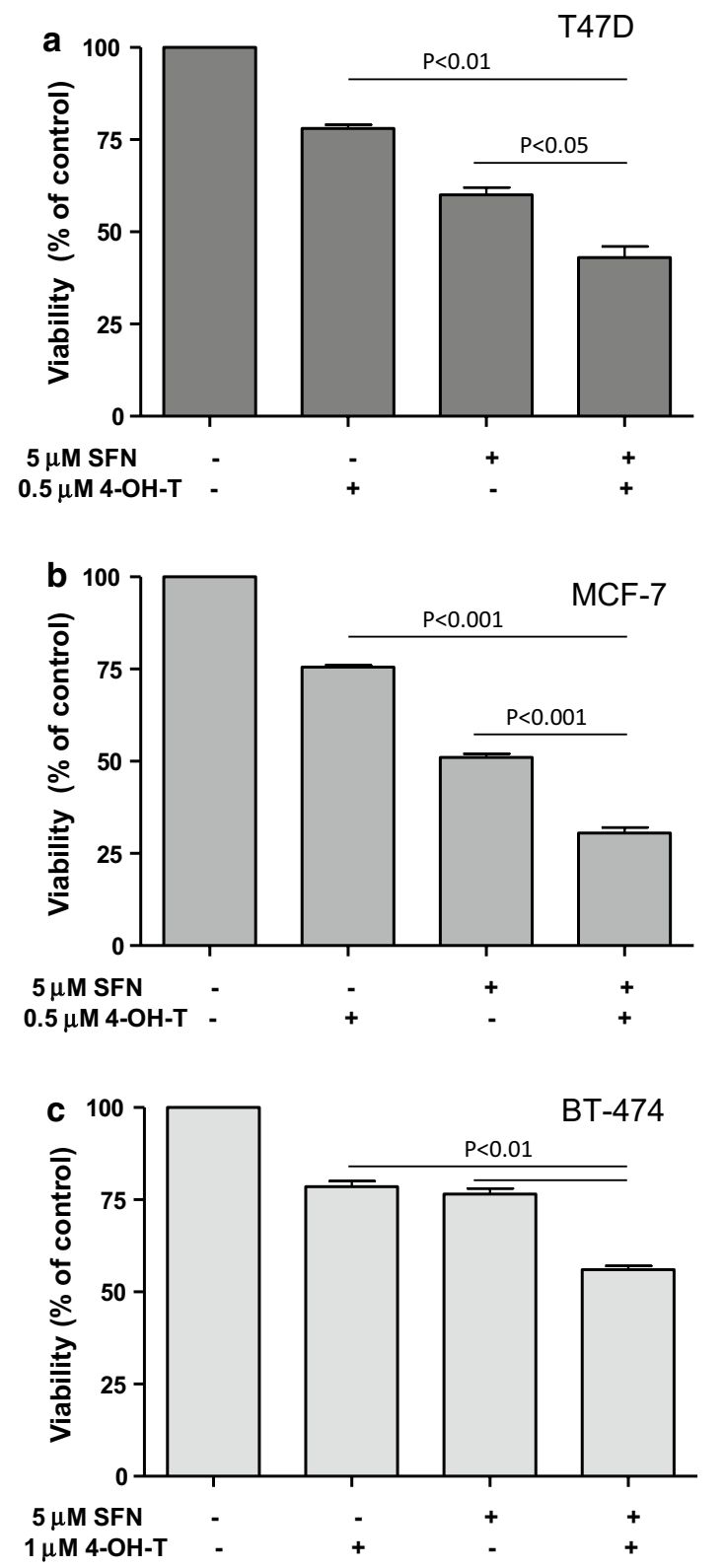

Fig. 2 Effect of 96-h treatment with sulforaphane (SFN, $5 \mu \mathrm{M}$ ), 4-hydroxytamoxifen (4-OH-T: $0.5 \mu \mathrm{M}$ in $\mathbf{a}$ and $\mathbf{b}$ or $1 \mu \mathrm{M}$ in $\mathbf{c}$ ) or both compounds on viability of T47D (a), MCF-7 (b) and BT-474 cells (c). Viability was assayed by MTT method as described in "Materials and methods". Results shown are mean \pm SE of three independent experiments performed in triplicate. $p$ values were calculated by one-way ANOVA followed by Bonferroni's multiple comparison test than mono-treatment is due to synergistic action of the used compounds, we calculated a combination index (CI) for the nonconstant ratio combinations using the method of Chou and Talaly and data from the MTT viability assays (linear correlation coefficient for each drug in the growth inhibition plot was $>0.9$ ). As shown in Table 1 , CI values for tested drug combinations were below 1 , which indicates synergism.
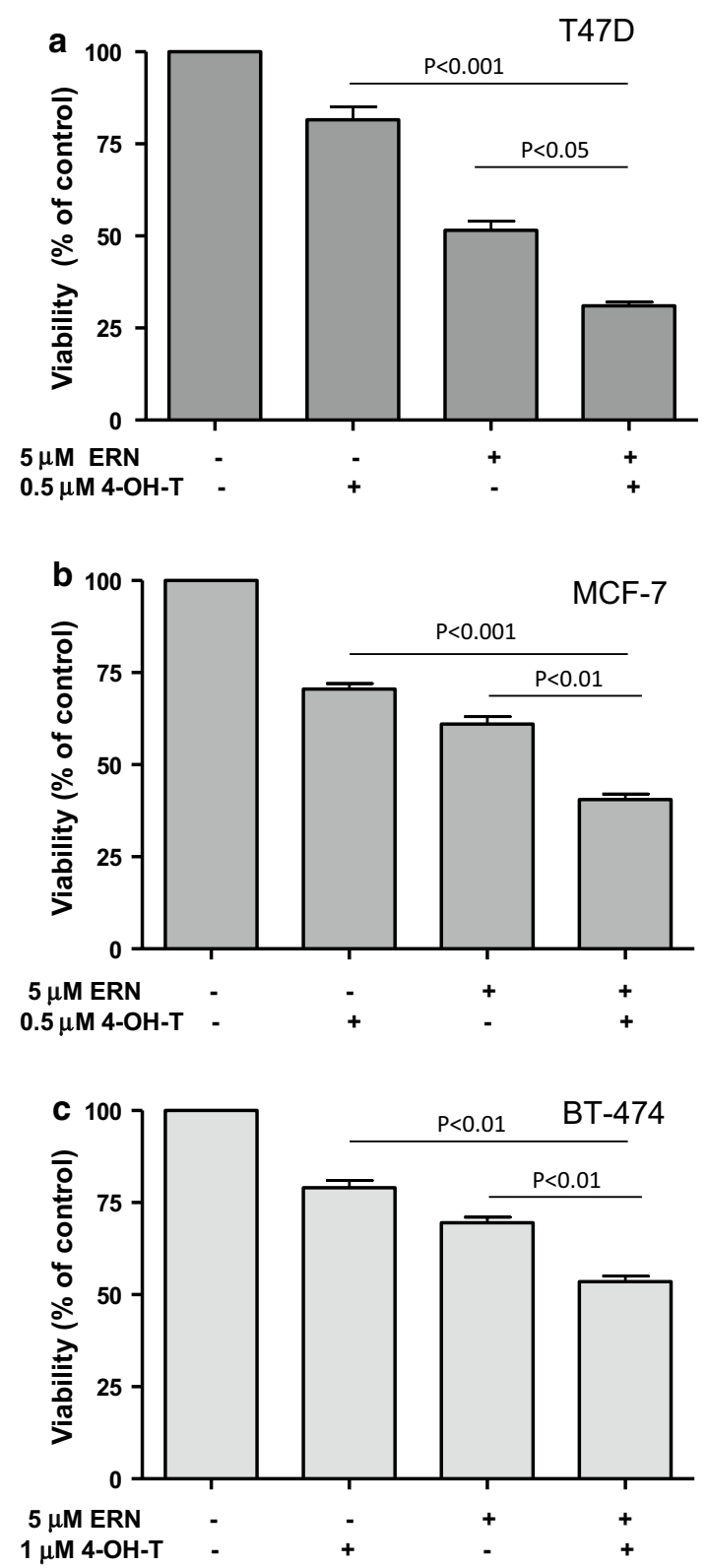

Fig. 3 Effect of 96-h treatment with erucin (ERN, $5 \mu \mathrm{M}$ ), 4-hydroxytamoxifen (4-OH-T: $0.5 \mu \mathrm{M}$ in $\mathbf{a}$ and $\mathbf{b}$ or $1 \mu \mathrm{M}$ in c) or both compounds on viability of T47D (a), MCF-7 (b) and BT-474 cells (c). Results shown are mean \pm SE of three independent experiments performed in triplicate. $p$ values were calculated by one-way ANOVA followed by Bonferroni's multiple comparison test 
Table 1 Combination indexes of sulforaphane (SFN) or erucin (ERN) and 4-hydroxytamoxifen (4-OH-T) in breast cancer cells. $\mathrm{CI}<1$ indicates synergism

\begin{tabular}{lll}
\hline Cell line & Combination & CI \\
\hline T47D & SFN $(5 \mu \mathrm{M})+4-\mathrm{OH}-\mathrm{T}(0.5 \mu \mathrm{M})$ & 0.71 \\
& ERN $(5 \mu \mathrm{M})+4-\mathrm{OH}-\mathrm{T}(0.5 \mu \mathrm{M})$ & 0.36 \\
MCF-7 & SFN $(5 \mu \mathrm{M})+4-\mathrm{OH}-\mathrm{T}(0.5 \mu \mathrm{M})$ & 0.63 \\
& ERN $(5 \mu \mathrm{M})+4-\mathrm{OH}-\mathrm{T}(0.5 \mu \mathrm{M})$ & 0.66 \\
BT-474 & SFN $(5 \mu \mathrm{M})+4-\mathrm{OH}-\mathrm{T}(1 \mu \mathrm{M})$ & 0.81 \\
& ERN $(5 \mu \mathrm{M})+4-\mathrm{OH}-\mathrm{T}(1 \mu \mathrm{M})$ & 0.61 \\
\hline
\end{tabular}

\section{Effect of isothiocyanate and 4-hydroxytamoxifen co-treatment on apoptosis induction in the analyzed breast cancer cell lines}

To elucidate whether decreased viability of breast cancer cells treated with the combination of ITC and 4-hydroxytamoxifen results from an apoptosis induction, we compared caspase-dependent cleavage of PARP in control cells as well as in cells treated with ITC and/or the drug. The immunoblotting analysis showed that 4-hydroxytamoxifen at $0.5 \mu \mathrm{M}$ in T47D cells had no effect on PARP status while at $0.5 \mu \mathrm{M}$ in MCF-7 cells and at $1 \mu \mathrm{M}$ concentration in BT-474 cell line had a minimal effect on apoptosis induction as assessed by PARP cleavage (Figs. 4, 5). Sulforaphane and erucin at $5 \mu \mathrm{M}$ concentrations induced PARP cleavage with intensity dependent on the cell line. However, combined treatment with SFN or ERN and 4-hydroxytamoxifen further elevated PARP cleavage (Figs. 4, 5).

It has been previously reported that ITC induce apoptosis mainly through the mitochondrial pathway; thus, we determined the level of anti-apoptotic Bcl-2 and pro-apoptotic Bax upon treatment with ITC and/or the drug. As shown in Figs. 4, 5, combinations of SFN or ERN with 4-hydroxytamoxifen decreased the Bcl-2 level most efficiently (to $30-50 \%$ of the level seen in control cells), while the Bax level was elevated (about $50 \%$ above the level seen in controls). Thus, reduction of $\mathrm{Bcl}-2 / \mathrm{Bax}$ ratio in cells treated with combinations of compounds might lead to mitochondria-mediated induction of apoptosis. As mitochondrial dysfunction may trigger formation of lipid droplets, we determined the level of adipocyte differentiation-related protein (ADRP) which decorates membranes of these organelles. As can be seen in Figs. 4 and 5, the ADRP level was elevated in cells treated with SFN or ERN and 4-hydroxytamoxifen when compared with cells treated with a single compound. Finally, the level of survivin, which is an inhibitor of caspase 3, 7 and 9, and is a mitosis promoter, was efficiently reduced by combined treatment as compared to controls and a single compound treatment, excluding BT-474 cells, where ERN alone increased survivin level
Fig. 4 Effect of co-treatment of breast cancer cell lines with 4-hydroxytamoxifen and sulforaphane on PARP cleavage and levels of Bcl-2, Bax, survivin and ADRP. T47D (a) and MCF-7 (b) cells were treated with $5 \mu \mathrm{M}$ sulforaphane (SFN), and/or $0.5 \mu \mathrm{M}$ 4-hydroxytamoxifen (4-OH-T). BT-474 (c) cells were treated with $5 \mu \mathrm{M}$ sulforaphane (SFN) and/or $1 \mu \mathrm{M}$ 4-hydroxytamoxifen (4-OHT). Blots were stripped and reprobed with anti- $\beta$-actin antibody to ensure equal protein loading. Results are plotted as mean $\pm \mathrm{SE}$ from three independent experiments, *significantly different compared with single agent-treated samples or **significantly different compared with one of the single agent-treated samples by one-way ANOVA followed by Bonferroni's multiple comparison test. Data for PARP refer to the faster migrating band marked as $*$ and are given relative to samples treated with SFN alone. Blots shown are representative of at least three independent experiments

about $100 \%$ above control, and although combination with 4-hydroxytamoxifen lowered its amount, it was still higher than in the drug-only-treated cells (Fig. 4).

\section{Impact of the co-treatment of T47D, MCF-7 and BT-474 cells with 4-hydroxytamoxifen and isothiocyanates on induction of autophagy}

Numerous studies have shown that MCF-7 and T47D cells undergo autophagy under adverse conditions, such as tamoxifen treatment. We investigated whether ITC induce autophagy in these cells and whether co-treatment with 4-hydroxytamoxifen and ITC potentiates this process. We analyzed conversion of soluble LC3-I to the lipid-bound LC3-II form which is an established marker of autophagy. As can be seen in Fig. 6a, c, clear intensification of LC3 processing (increased level of LC3-II and decreased level of LC3-I) was observed in T47D and MCF-7 cells treated with combination of compounds. In BT-474 cells, combination of ITC and 4-hydroxytamoxifen slightly increased LC3-II, while the LC3-I form was still abundant as compared with control cells or cells treated with either drug alone (Fig. 6e). To reconcile if autophagy induced by the investigated compounds plays pro-survival or pro-death role, we applied wortmannin which inhibits first stages of this process and determined viability of cells. As shown in Fig. 6b, d, inhibition of autophagy induced by combination of SFN or ERN and 4-hydroxytamoxifen in T47D and MCF-7 cells reduced their viability, which suggests that in these cell lines, autophagy plays a protective role. On the contrary, BT-474 cells revealed increased survival upon treatment with combinations when autophagy was inhibited (Fig. 6f), which suggests that in this case, autophagy contributes to cell death.

\section{Combined treatment decreases ability of cells to proliferate indefinitely}

As one of the main problems in anticancer therapies is recurrence of the disease, effective treatment should 


\section{a T47D}

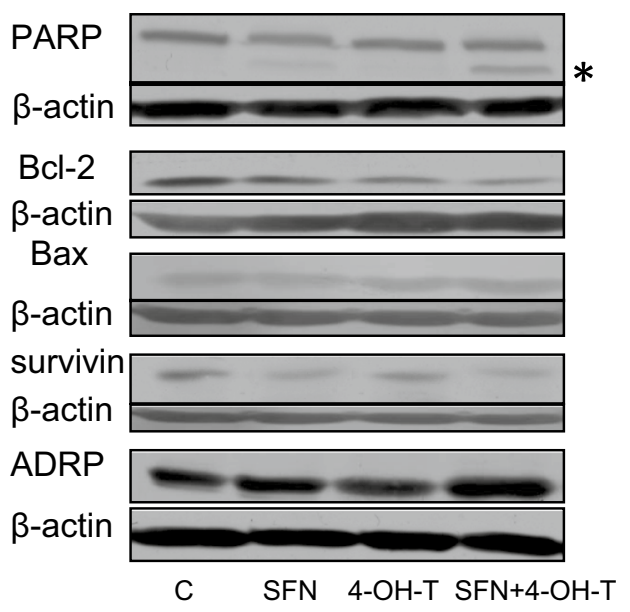

b $\mathrm{MCF}-7$
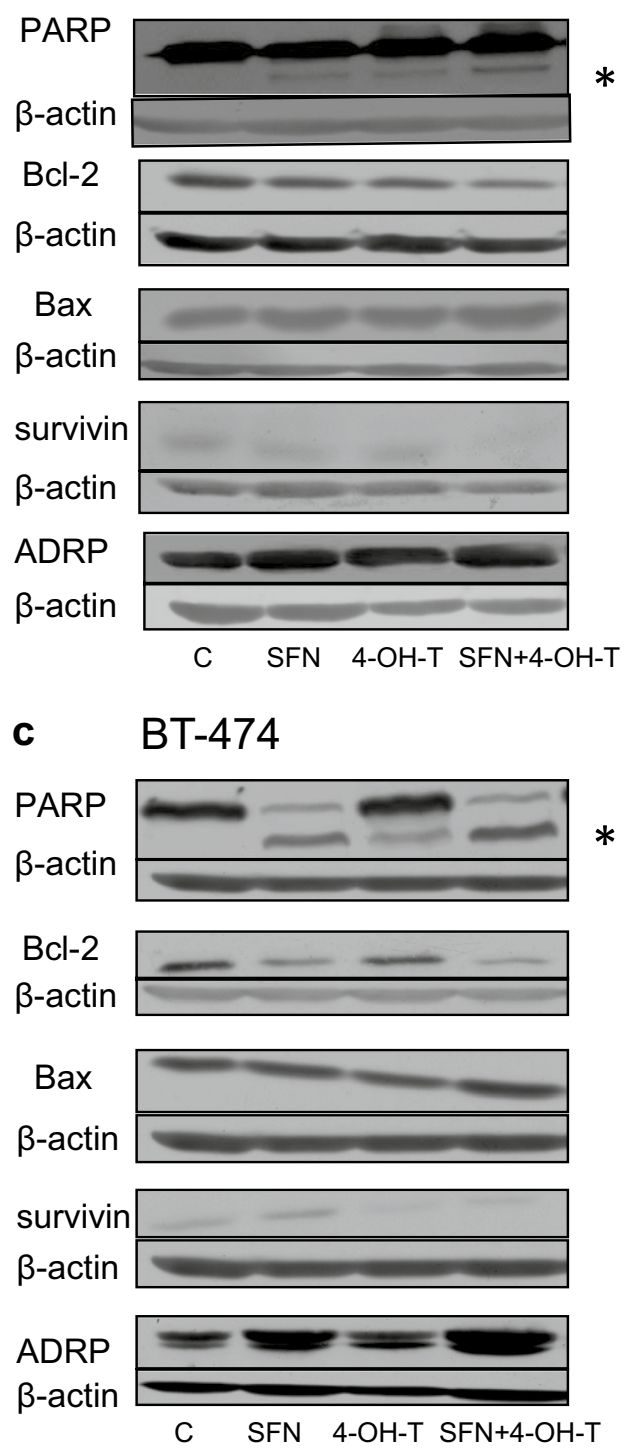
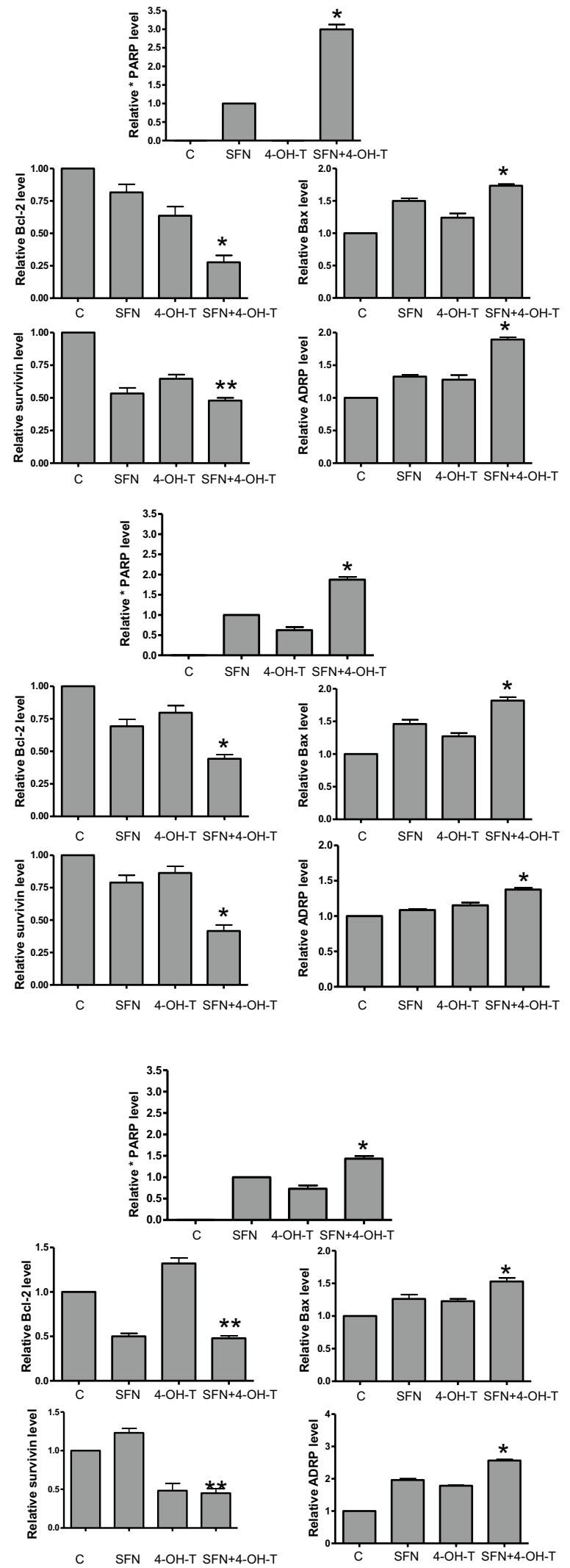


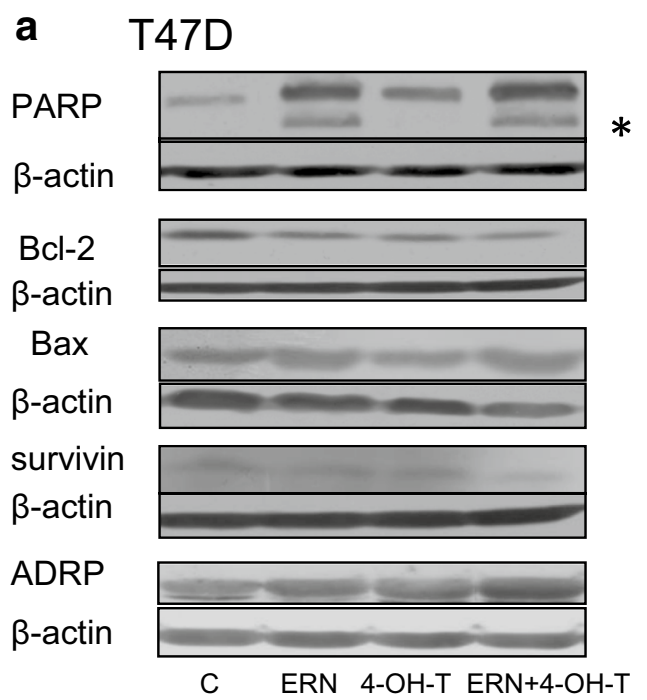

b $\mathrm{MCF}-7$

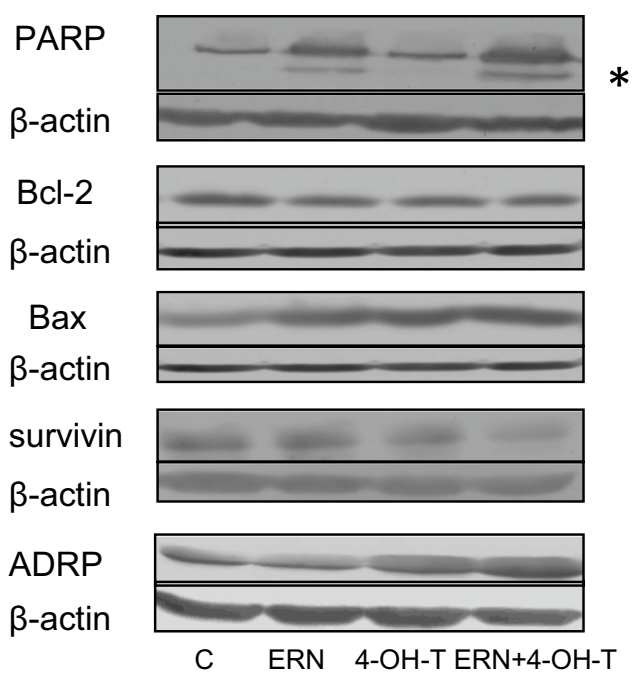

C $\quad \mathrm{BT}-474$

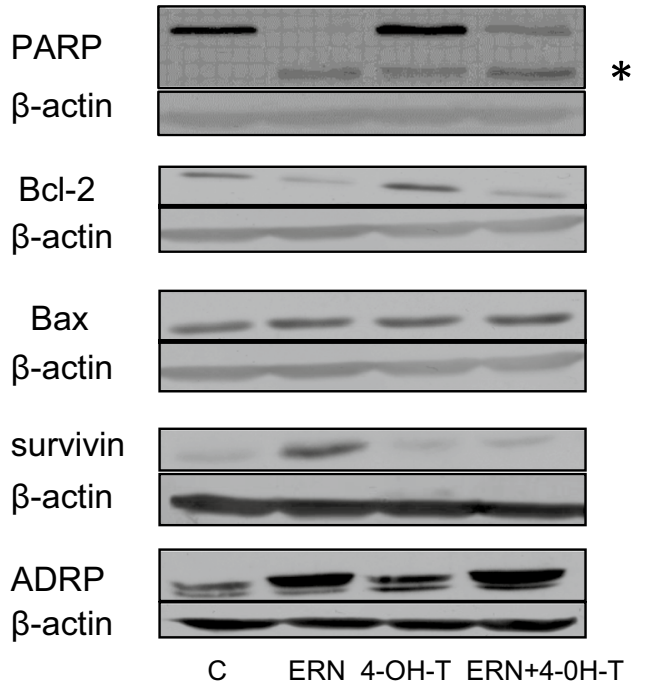

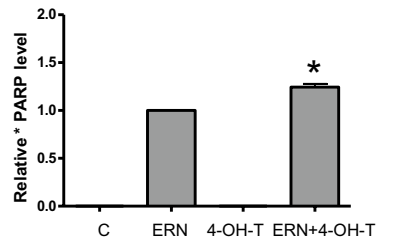
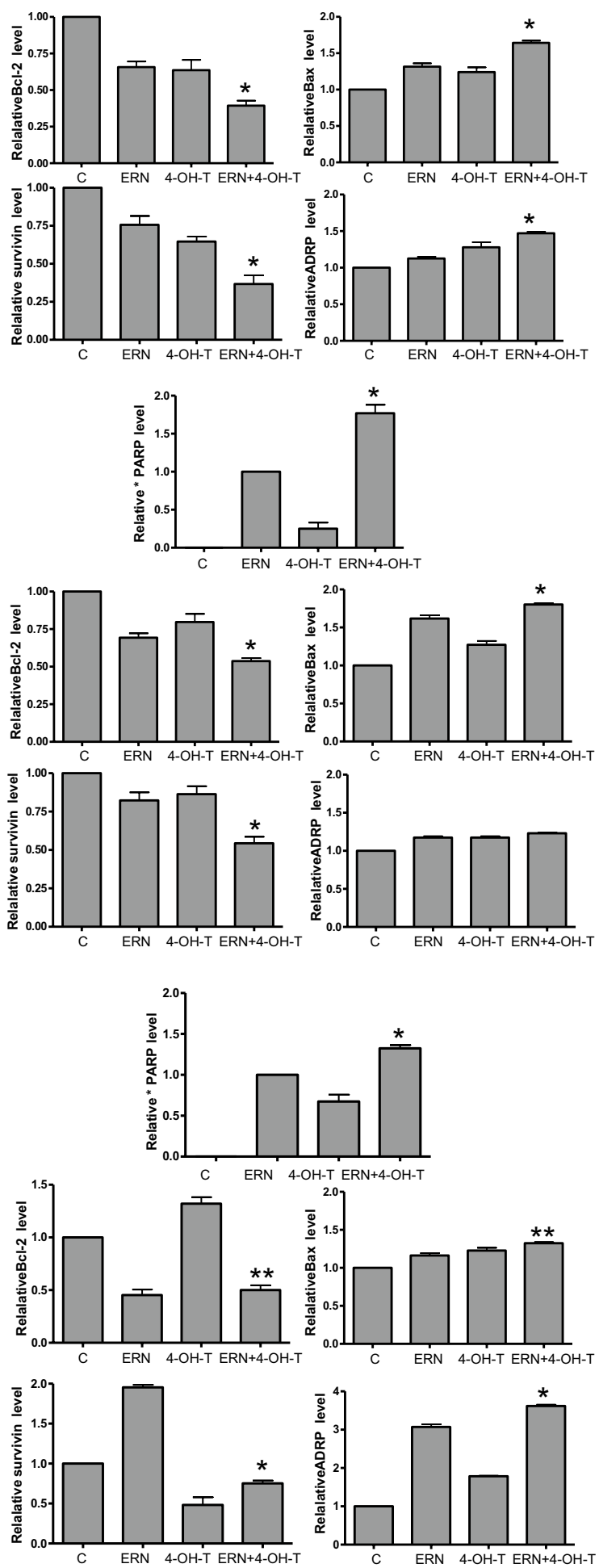
4 Fig. 5 Effect of co-treatment of breast cancer cell lines with 4-hydroxytamoxifen and erucin on PARP cleavage, levels of Bcl-2, Bax, survivin and ADRP. T47D (a) and MCF-7 (b) cells were treated with $5 \mu \mathrm{M}$ erucin (ERN) and/or $0.5 \mu \mathrm{M}$ 4-hydroxytamoxifen (4-OHT). BT-474 (c) cells were treated with $5 \mu \mathrm{M}$ erucin (ERN) and/or $1 \mu \mathrm{M}$ 4-hydroxytamoxifen (4-OH-T). Blots were stripped and reprobed with anti- $\beta$-actin antibody to ensure equal protein loading. Results are plotted as mean \pm SE from 3 independent experiments, *significantly different compared with single agent-treated samples or **significantly different compared with one of the single agenttreated samples by one-way ANOVA followed by Bonferroni's multiple comparison test. Data for PARP refer to the faster migrating band marked as * and are given relative to samples treated with ERN alone. Blots shown are representative of at least three independent experiments

irreversibly eliminate cancer cells. Thus, we assessed the clonogenic potential of breast cancer cells treated with 4-hydroxytamoxifen and/or ITC for 8 days and allowed for their recovery in a drug-free medium for 2-4 weeks. Results presented in Fig. 7 clearly show that clonogenic potential of cells treated with combination of 4-hydroxytamoxifen and SFN is significantly lower than in the case of cells treated with each agent alone. Moreover, combined treatment reduces clonogenicity compared to controls by about $60 \%$ (MCF-7 and BT-474 cells) or $70 \%$ (T467D cells). Erucin per se is a highly cytotoxic agent (reduces clonogenic potential compared to controls to $40 \%$ in MCF-7 cells and 14-18\% in T47D and BT-474 cells). Its combination with 4-hydroxytamoxifen potentiates cytotoxicity in MCF-7 and T47D cell lines by about twofold (Fig. 7a, b), while has no further effect on clonogenicity of BT-474 cells (Fig. 7c).

\section{Isothiocyanates sensitize tamoxifen-resistant ER-positive breast cancer cells to the drug}

As acquired resistance to tamoxifen occurs frequently, we decided to verify whether ITC affect sensitivity of tamoxifen-resistant cells to this drug. Thus, we established T47D and MCF-7 derivatives (T47D tamR and MCF-7 tamR, respectively), which were able to grow in media containing $500 \mathrm{nM}$ of 4-hydroxytamoxifen (Fig. 8a-d) and retained ER expression (data not shown). T47D tamR cell line also appeared to be less sensitive to sulforaphane or erucin than parental cell line (Fig. 8a, b). Importantly, ITC sensitized tamoxifen-resistant cells to the drug: Combination of SFN or ERN with $500 \mathrm{nM}$ of 4-hydroxytamoxifen caused a statistically significant drop in viability of the cells tested as compared to the treatment with any single compound (Fig. 8a-d).

It has been shown that sulforaphane effectively lowers viability of both ER-positive and ER-negative breast cancer cells [45, 49]. To determine whether SFN or ERN sensitize cells to 4-hydroxytamoxifen in an ER-independent manner, we used ER-negative MDA-MB-231 cell line, which appeared resistant to the drug at concentrations used by us for ER-positive cells $(0.5$ and $1 \mu \mathrm{M})$ (Fig. 8e). Combination of $5 \mu \mathrm{M}$ sulforaphane or erucin with $500 \mathrm{nM}$ of 4-hydroxytamoxifen did not potentiate sensitivity of MDAMB-231 cells to any single agent. However, we observed enhanced activity of the combination of ITC and 4-hydroxytamoxifen toward ER-negative cells when 4-hydroxytamoxifen was applied at higher, cytotoxic concentration $(5 \mu \mathrm{M})$ (Fig. 8f, g). Combination of ERN with $5 \mu \mathrm{M}$ 4-hydroxytamoxifen reduced viability of MDA-MB-231 more efficiently than any compound used alone (Fig. 8g).

\section{Discussion}

Epidemiological studies indicate that frequent intake of cruciferous vegetables rich in ITC may reduce the risk for developing cancers [60]. Studies performed with laboratory animals and cancer cell lines confirmed this notion and gave insight into molecular mechanism of not only chemopreventive but also anticancer activities of these phytochemicals (for review, see [21]). It has been previously documented for different breast cancer cell lines that sulforapahane downregulates ER- $\alpha$, EGFR and HER2 proteins [49] as well as PI3K-Akt-mTOR signaling pathway [45] whose overactivity may contribute to resistance of ER-positive cancers to endocrine therapy. It has been also shown that sulforaphane at $10 \mu \mathrm{M}$ concentration potentiated antiproliferative activity of tamoxifen used at $1 \mu \mathrm{M}$ concentration in the ER-negative MDA-MB-231 cells, which was further enhanced by green tea polyphenols due to chromatin modification and reactivation of the ER expression [38]. The purpose of our study was to experimentally test the hypothesis that ITC at relatively low concentration may intensify the anti-proliferative effect of 4-hydroxytamoxifen on ER-positive breast cancer cell lines. We used two structurally related ITC and breast cancer cell lines which differ in the amount of ER and HER2 receptors as well as generation times.

We demonstrate that combinations of 4-hydroxytamoxifen at a low inhibitory concentration and any isothiocyanate at concentrations lower than their $\mathrm{IC}_{50}$ values inhibit cell proliferation of ER-positive human breast cancer cells more efficiently than any compound used alone. The results of the MTT tests show that BT-474 cell line was the least sensitive to the drug or ITC. It could be related to a slower growth rate of BT-474 cells. Their doubling time exceeds $100 \mathrm{~h}$, while doubling rate for MCF-7 cells is about 29 and T47D-about $32 \mathrm{~h}$. Moreover, these cell lines differ in the expression levels of growth factor receptor genes. BT-474 cell line is characterized by comparable level of ER (11.3 
a

\section{T47D}
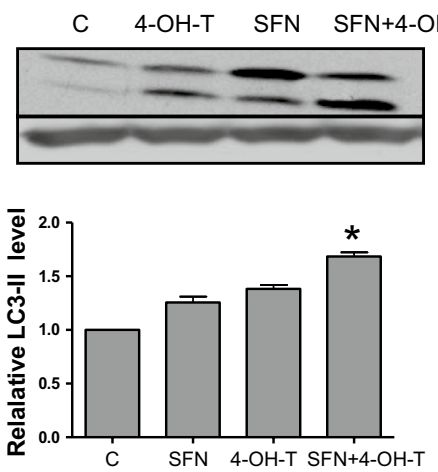

C $\mathrm{MCF}-7$
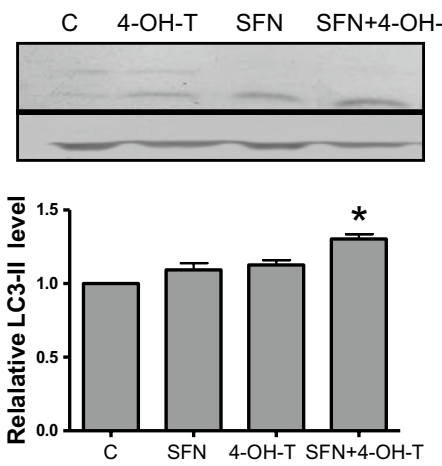

e
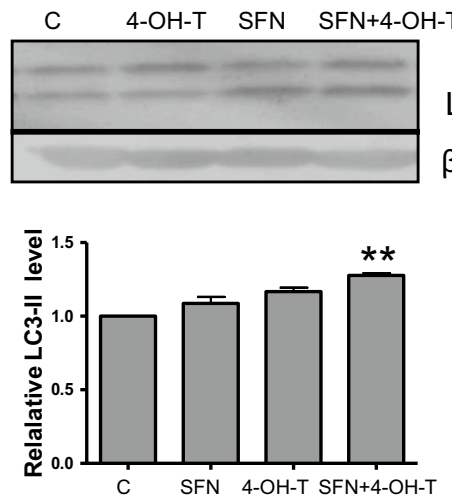
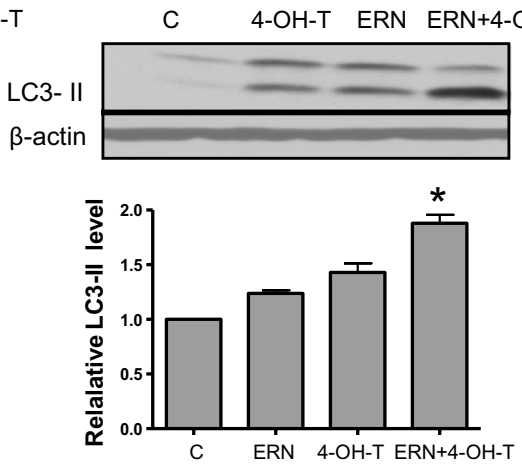

C 4-OH-T ERN ERN+4-OH-T

C 4-OH-T ERN ERN+4-OH-T
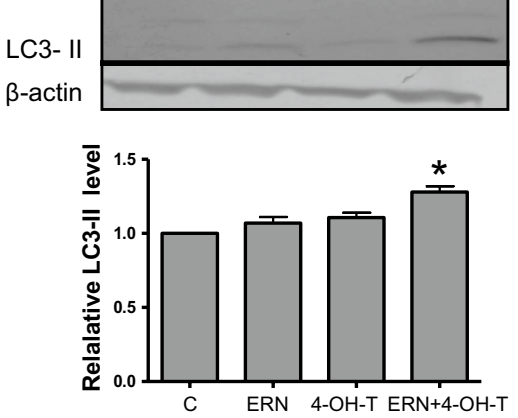

b

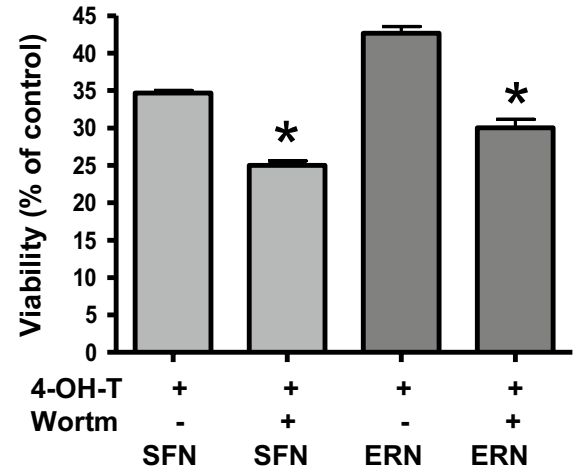

d

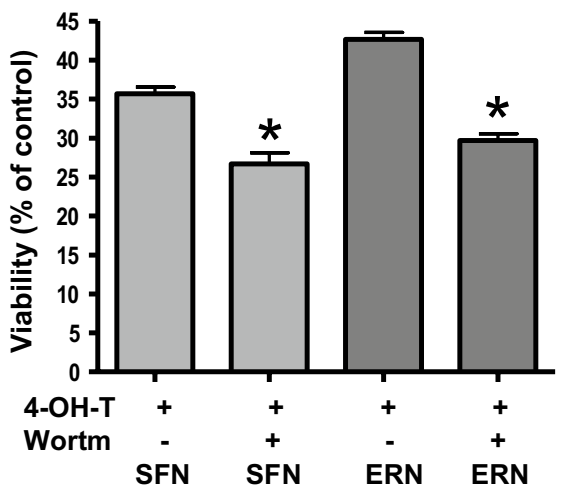

f

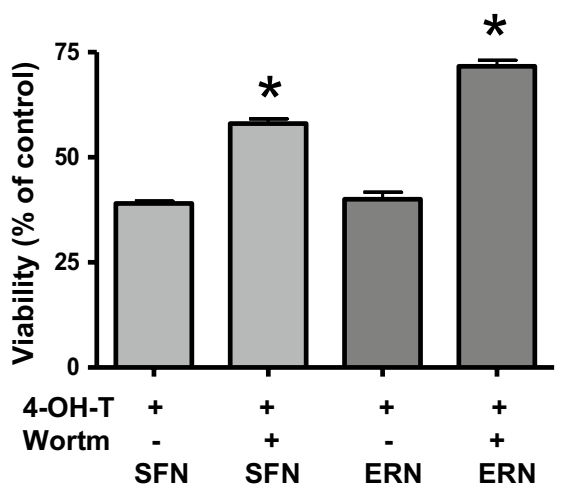

Fig. 6 Autophagy process in T47D (a, b), MCF-7 (c, d) and BT-474 cells $(\mathbf{e}, \mathbf{f})$ treated with sulforaphane, erucin, 4-hydroxytamoxifen or combinations. T47D and MCF-7 cells were treated with $5 \mu \mathrm{M}$ sulforaphane (SFN), $5 \mu \mathrm{M}$ erucin (ER) and/or $0.5 \mu \mathrm{M}$ 4-hydroxytamoxifen (4-OH-T), and BT-474 cells were treated with $5 \mu \mathrm{M} \mathrm{SFN}$, $5 \mu \mathrm{M}$ ERN and/or $1 \mu \mathrm{M} 4-\mathrm{OH}-\mathrm{T}$. a, c, e LC3 processing (autophagy marker) was determined by immunoblotting. The blots were stripped and reprobed with anti- $\beta$-actin antibody to ensure equal protein load-

fmol/mg protein) but much higher level of HER2/neu $(12,256 \mathrm{fmol} / \mathrm{mg}$ protein) when compared to MCF-7 cells $($ ER $-11.5 \mathrm{fmol} / \mathrm{mg}$ protein and HER2-297 fmol/ $\mathrm{mg}$ protein) or T47D (ER-16.7 fmol/mg protein and ing. Results are plotted as mean \pm SE from 3 independent experiments, *significantly different compared with both single agenttreated samples or **significantly different compared with one of the single agent-treated samples by one-way ANOVA followed by Bonferroni's multiple comparison test. b, d, f Impact of autophagy on viability of cells treated with indicated compounds was assessed by SRB method upon autophagy inhibition by $5 \mathrm{nM}$ wortmannin. $* p<0.001$

HER2-165 fmol/mg protein) [34]. Preclinical research and clinical trials have revealed that magnitude of the response to treatment with tamoxifen correlated with the ER level and its crosstalk with other growth factor 
Fig. 7 Effect of treatment with sulforaphane (SFN), erucin (ERN), 4-hydroxytamoxifen (4-OH-T) or combination of isothiocyanate and the drug on clonogenic potential of T47D (a), MCF-7 (b) and BT-474 cells (c). Cells were exposed to $5 \mu \mathrm{M} \mathrm{SFN}, 5 \mu \mathrm{M}$ ERN and/or $0.5 \mu \mathrm{M}(\mathbf{a}, \mathbf{b})$ or $1 \mu \mathrm{M}$ (c) 4-hydroxytamoxifen for 8 days. After that time, cells were replated at lower confluences and allowed to growth for 2 (T47D and MCF-7) or 4 weeks (BT-474) in drug-free medium. Colonies arisen from cells retaining proliferative potential were counted, and results are shown as mean $\pm \mathrm{SE}$ of two independent experiments performed in duplicate. Statistical significance of difference was determined by one-way ANOVA followed by Bonferroni's multiple comparison test, and $* * p<0.001$ as compared to ITC and 4-OH-T alone, $* p<0.001$ as compared to 4-OH-T only and $p<0.05$ as compared to erucin only, $* p<0.001$ as compared to 4-OH-T only and $p>0.05$ as compared to erucin only
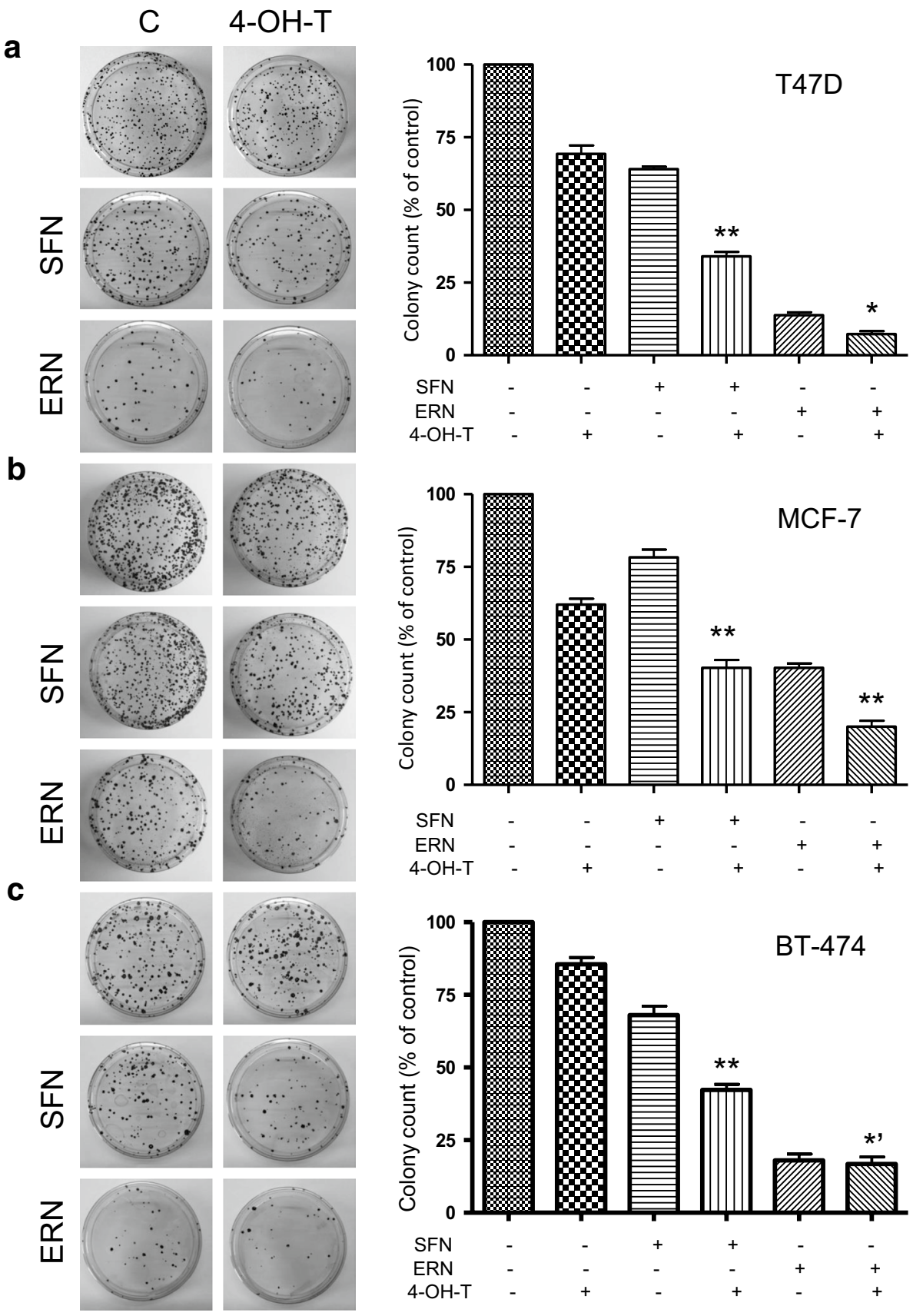

receptors, such as HER2 [12, 54] which may explain higher resistance of BT-474 cells to treatment with 4-hydroxytamoxifen or ITC. However, despite this, viability of BT-474 cells was significantly decreased in experimental variants treated with a combination of phytochemicals (sulforaphane or erucin) and 4-hydroxytamoxifen compared to cells treated with any compound alone. Moreover, combinations of 4-hydroxytamoxifen at a low concentration with SFN or ERN efficiently inhibited clonogenic potential of the breast cancer cells. It is worth noting that ability of cells to proliferate was significantly reduced after only 8 days of treatment with combinations and subsequent cessation of therapy. Longer therapy might have a more pronounced effect.

Several studies have shown that high concentrations of erucin and sulforaphane induce apoptosis-associated proteolytic cleavage of poly(ADP-ribose) polymerase in different cancer cell lines $[39,44,56]$. Here we demonstrate that combinations of sulforaphane or erucin with 4-hydroxytamoxifen at low concentrations induce apoptosis of breast cancer cell lines more efficiently than any compound used alone. Substantial drop in Bcl-2/Bax ratio upon combined treatment, as well as an increased level of ADRP, the marker of mitochondrial stress-mediated lipid droplet 
a $\quad$ T47D tamR

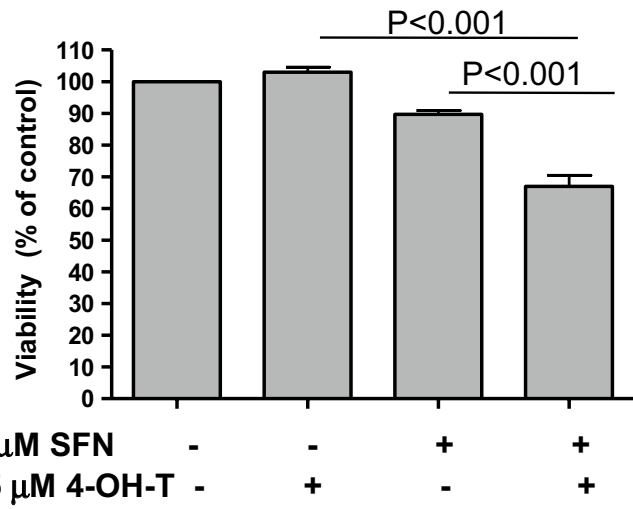

c MCF-7 tamR

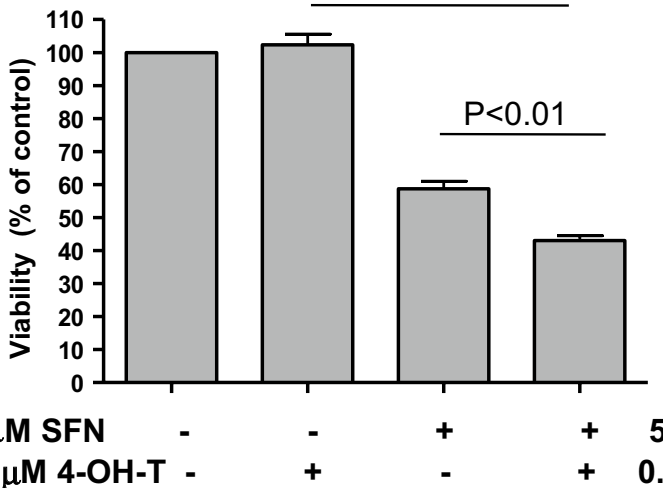

b

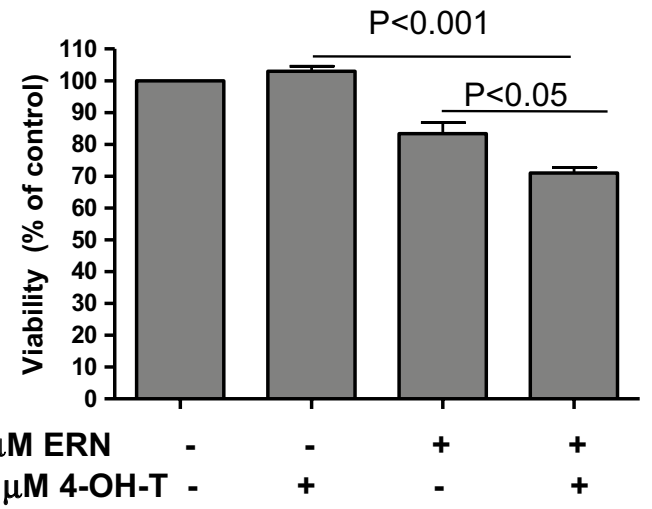

d

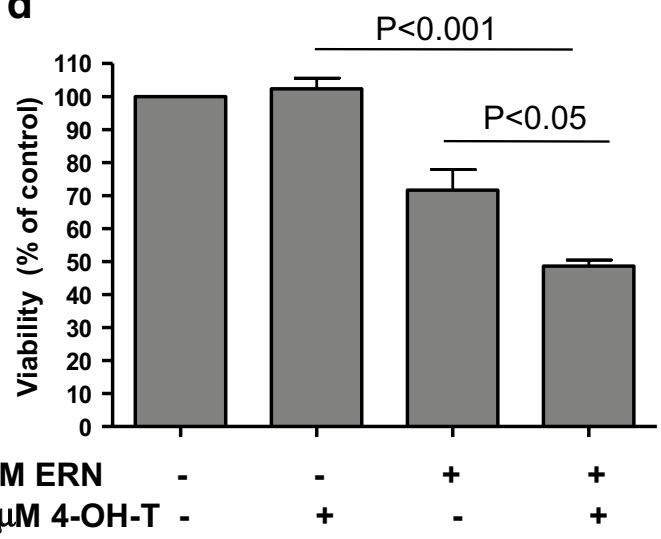

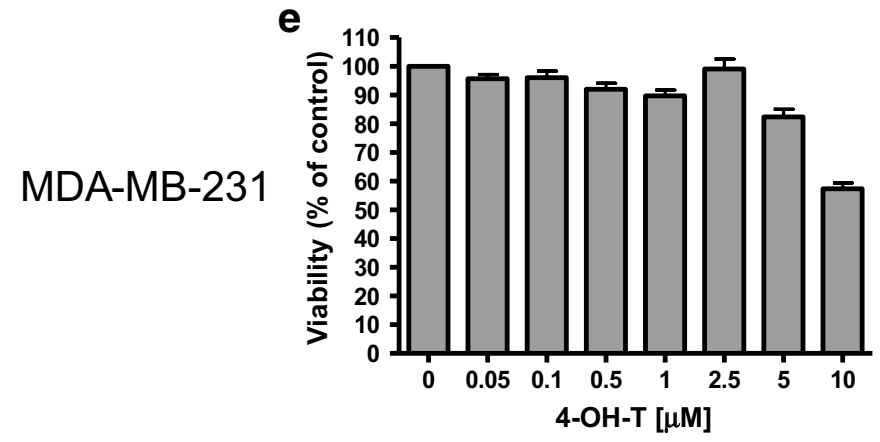

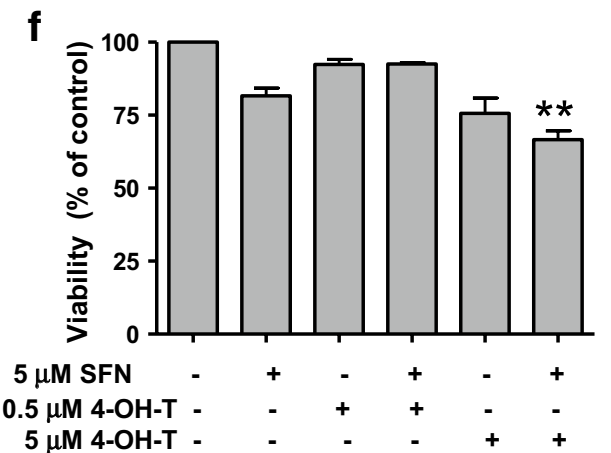

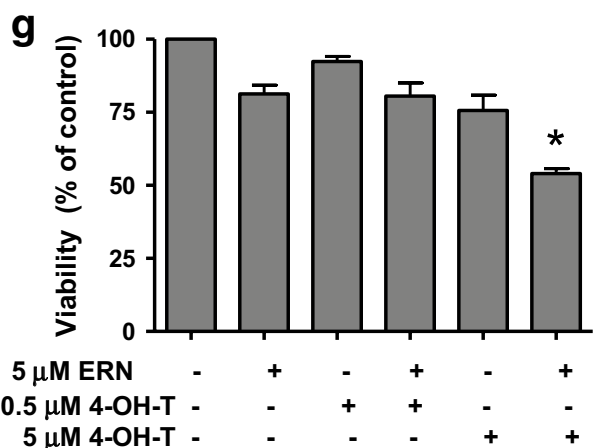

formation, points toward involvement of mitochondrial pathway in apoptosis induction in each cell line; however, death receptor pathway cannot be excluded.
We also determined the effect of single as well as combined treatment with ITC and 4-hydroxytamoksifen on survivin level in all three cell lines. Survivin inhibits apoptosis 
4 Fig. 8 Isotiocyanates sensitize to 4-hydroxytamoxifen drug-resistant cells. Tamoxifen-resistant T47D (T47D tamR) and MCF-7 (MCF-7 tamR) derivatives were obtain as described in "Materials and methods". Viability of T47D tamR (a, b) or MCF-7 tam R (c, d) after 96-h treatment with sulforaphane (SFN, $5 \mu \mathrm{M}$ ), erucin (ERN, $5 \mu \mathrm{M}$ ) or/ and 4-hydroxytamoxifen (4-OH-T: $0.5 \mu \mathrm{M}$ ) was assessed by MTT assay. e-g Viability of ER-negative MDA-MB-231 cells was determined after treatment with increasing concentrations of 4-hydroxytamoxifen (4-OH-T) (e), SFN (5 $\mu \mathrm{M})$ and/or 4-OH-T (0.5 $\mu \mathrm{M}$ or $5 \mu \mathrm{M})(\mathbf{f})$, ERN $(5 \mu \mathrm{M})$ and/or $4-\mathrm{OH}-\mathrm{T}(0.5 \mu \mathrm{M}$ or $5 \mu \mathrm{M})(\mathbf{g})$. Results shown are mean \pm SE of three independent experiments performed in triplicate. *Significantly different compared with both single agent-treated samples or **significantly different compared with SFN-only-treated samples by one-way ANOVA followed by Bonferroni's multiple comparison test

and promotes cell proliferation and angiogenesis. This protein is undetectable in majority of normal adult tissues; however, it is often overexpressed in tumors, including breast cancers (in 70-90\% of cases) [3, 33]. High level of survivin correlates with progression of cancer and resistance to therapies [2, 63]; thus, its targeting might improve efficacy of chemo- or radiotherapies [33]. We observed that SFN, ERN or 4-hydroxytamoxifen downregulates survivin to a similar extent in T47D and MCF-7 cells and combinations of the drug and ITC potentiate this effect. Interestingly, in BT-474 cells, ITC alone elevated the survivin level when compared with controls, which might explain lower sensitivity of this cell line to SFN or ERN. However, their combination with the 4-hydroxytamoxifen decreased the survivin level. Here, the net result of combined treatment on cell viability might be caused not only through survivin but also by Bcl-2 level modulation. The Bcl-2 level changed in an opposite manner to that of survivin: It was elevated by 4-hydroxytamoxifen and reduced by ITC and their combinations with the drug. Levels of anti-apoptotic proteins are regulated by multiple pathways; thus, the impact of chemicals used by us on Bcl-2 or survivin expression might be related to the genetic background of the cells used.

We also observed that ITC and 4-hydroxytamoxifen induce processing of the LC3 protein, a specific marker of autophagosomes [29], especially when used in combinations. Autophagy is one of the most important strategies for protein degradation and protein/organelle quality control mechanism, and during cellular stress, it provides nutrients to support metabolism [14]. Accumulated evidence suggests that a basal or slightly increased level of autophagy can protect cells against apoptosis; however, prolonged or intensive autophagy can lead to cell death [7, 46]. For instance, SFN-induced autophagy in prostate as well as breast cancer cells played a protective role $[22,31]$ but benzyl isothiocyanate-induced autophagy in breast cancer cells contributed to their death [62]. The role of autophagy induced by tamoxifen or its metabolites in breast cancer cells is controversial. Initial studies documented that tamoxifen and 4-hydroxytamoxifen caused an autophagic death (also referred to as type II cell death) of MCF-7 cells $[9,10]$. However, more recent data indicate that in response to 4-hydroxytamoxifen, only a small part of cell population dies, while majority of cells are arrested in growth and viable. Interestingly, elevation of autophagy in living cells decreased drug-induced death, while autophagy inhibition resulted in a more robust caspase-dependent death of MCF-7 cells [52]. Moreover, the authors have shown that in tamoxifen-resistant MCF-7 cells, autophagy inhibition sensitized these cells to the antiestrogen [52]. In our study, the combined treatment with ITC and 4-hydroxytamoxifen also induced protective autophagy in MCF-7 and T47D cell lines, while in BT-474 cells contributed to their lower survival. The reason for the observed differences is not known at this moment; however, it was previously reported that BT-474 cells contain a high basal level of autophagosomes [16], which is in agreement with our observation showing an increased LC3-II level even in nontreated cells. Thus, it is possible that upon treatment with ITC and 4-hydroxytamoxifen autophagy reaches the threshold necessary for cell death.

Finally, we show that SFN or ERN efficiently sensitized tamoxifen-resistant variants of MCF-7 and T47D cells to 4-hydroxytamoxifen. It seems that synergistic activity of ITC and the drug used at a low concentration $(0.5 \mu \mathrm{M})$ is ER dependent, which is evidenced by the fact that our T47D tamR and MCF-7 tamR cells retained this receptor and are sensitive to the combined treatment, while in the MDA-MB-231 cells, which are devoid of ER, ITC do not abrogate resistance to $0.5 \mu \mathrm{M}$ 4-hydroxytamoxifen. On the other hand, ITC, especially erucin, might potentiate the cytotoxic activity of the drug used at $5 \mu \mathrm{M}$ concentration. However, high concentrations of tamoxifen have been shown to have an ER-independent nongenomic effect in ER-negative breast and other cancer cells [18, 30, 64]. Thus, it is possible that the mechanism of sensitization to 4-hydroxytamoxifen by ICT might be related to the drug dose.

Important question arises when coming to in vivo use of combined therapy: whether micromolar concentrations of ITC are achievable in humans. In case of SFN, it has been shown that in human subjects who ingested $100 \mathrm{~g}$ of broccoli as a soup, its peak plasma concentrations reached $2.2 \mu \mathrm{M}$ [20]. A more recent study shows that $3 \mathrm{~h}$ after consumption of broccoli sprouts providing $200 \mu \mathrm{mol}$ SFN, plasma levels of total SFN metabolites reached about $2 \mu \mathrm{M}$ concentration [4]. In rats, after an oral dose of $50 \mu \mathrm{mol}$ of SFN was delivered, its plasma concentration peaked around $20 \mu \mathrm{M}$ at $4 \mathrm{~h}$ after dosing [23]. The bioavailability of erucin is not known at this time. However, SFN and ERN are structurally similar and reveal similar pharmacokinetics. Moreover, interconversion of SFN to ERN has 
been reported in rats and humans [32, 61]. Concentration of these ITC in plasma or tissue after multiple dosing of pure compounds can be higher than after one dose of plant extract; however, it has not been investigated so far. In case of the drug, it has been shown that clinically relevant steady-state plasma concentrations of tamoxifen and its biologically active metabolites can be as high as $5 \mu \mathrm{M}$ in patient sera [47].

In conclusion, our data indicate that sulforaphane or erucin, used at relatively low concentrations, potentiate anticancer activity of 4-hydroxytamoxifen. This effect is mediated by downregulation of anti-apoptotic proteins such as Bcl-2 and survivin and in consequence by induction of cell death. This strategy allows for using tamoxifen at lower doses, hence decreasing the level of its toxicity and improving the risk-benefit profile of this agent. Moreover, it might protect against acquisition by cancer cells the drug-resistant phenotypes during therapy.

Acknowledgments We are grateful to Dr. Katarzyna Potrykus for language assistance. This investigation was supported by the National Science Centre (Poland), Project No. N N301 601740.

Conflict of interest The authors declare that they have no conflict of interest.

Open Access This article is distributed under the terms of the Creative Commons Attribution 4.0 International License (http://creativecommons.org/licenses/by/4.0/), which permits unrestricted use, distribution, and reproduction in any medium, provided you give appropriate credit to the original author(s) and the source, provide a link to the Creative Commons license, and indicate if changes were made.

\section{References}

1. Abbaoui B, Riedl KM, Ralston RA, Thomas-Ahner JM, Schwartz SJ, Clinton SK, Mortazavi A (2012) Inhibition of bladder cancer by broccoli isothiocyanates sulforaphane and erucin: characterization, metabolism, and interconversion. Mol Nutr Food Res 56:1675-1687. doi:10.1002/mnfr.201200276

2. Altieri DC (2008) Survivin, cancer networks and pathwaydirected drug discovery. Nat Rev Cancer 8:61-70

3. Ambrosini G, Adida C, Altieri DC (1997) A novel anti-apoptosis gene, survivin, expressed in cancer and lymphoma. Nat Med 3:917-921

4. Atwell LL, Hsu A, Wong CP, Stevens JF, Bella D, Yu TW, Pereira CB, Lohr CV, Christensen JM, Dashwood RH, Williams DE, Shannon J, Ho E (2015) Absorption and chemopreventive targets of sulforaphane in humans following consumption of broccoli sprouts or a myrosinase-treated broccoli sprout extract. Mol Nutr Food Res 59:424-433. doi:10.1002/mnfr.201400674

5. Azarenko O, Jordan MA, Wilson L (2014) Erucin, the major isothiocyanate in arugula (Eruca sativa), inhibits proliferation of MCF7 tumor cells by suppressing microtubule dynamics. PLoS One 9:e100599. doi:10.1371/journal.pone.0100599

6. Baumgarten SC, Frasor J (2012) Minireview: inflammation: an instigator of more aggressive estrogen receptor
(ER) positive breast cancers. Mol Endocrinol 26:360-371. doi:10.1210/me.2011-1302

7. Bilir A, Altinoz MA, Erkan M, Ozmen V, Aydiner A (2001) Autophagy and nuclear changes in FM3A breast tumor cells after epirubicin, medroxyprogesterone and tamoxifen treatment in vitro. Pathobiology 69:120-126. doi:10.1159/000048766

8. Bjornstrom L, Sjoberg M (2005) Mechanisms of estrogen receptor signaling: convergence of genomic and nongenomic actions on target genes. Mol Endocrinol 19:833-842. doi:10.1210/ me.2004-0486

9. Bursch W, Ellinger A, Kienzl H, Torok L, Pandey S, Sikorska M, Walker R, Hermann RS (1996) Active cell death induced by the anti-estrogens tamoxifen and ICI 164384 in human mammary carcinoma cells (MCF-7) in culture: the role of autophagy. Carcinogenesis 17:1595-1607

10. Bursch W, Hochegger K, Torok L, Marian B, Ellinger A, Hermann RS (2000) Autophagic and apoptotic types of programmed cell death exhibit different fates of cytoskeletal filaments. J Cell Sci 113(Pt 7):1189-1198

11. Chou TC, Talalay P (1984) Quantitative analysis of dose-effect relationships: the combined effects of multiple drugs or enzyme inhibitors. Adv Enzyme Regul 22:27-55

12. Chung YL, Sheu ML, Yang SC, Lin CH, Yen SH (2002) Resistance to tamoxifen-induced apoptosis is associated with direct interaction between Her2/neu and cell membrane estrogen receptor in breast cancer. Int J Cancer 97:306-312

13. Clemons M, Danson S, Howell A (2002) Tamoxifen ("Nolvadex"): a review. Cancer Treat Rev 28:165-180

14. Codogno P, Meijer AJ (2005) Autophagy and signaling: their role in cell survival and cell death. Cell Death Differ 12(Suppl 2):1509-1518. doi:10.1038/sj.cdd.4401751

15. Conaway CC, Wang CX, Pittman B, Yang YM, Schwartz JE, Tian D, McIntee EJ, Hecht SS, Chung FL (2005) Phenethyl isothiocyanate and sulforaphane and their $\mathrm{N}$-acetylcysteine conjugates inhibit malignant progression of lung adenomas induced by tobacco carcinogens in A/J mice. Cancer Res 65:8548-8557. doi:10.1158/0008-5472.CAN-05-0237

16. Di X, Zhang G, Zhang Y, Takeda K, Rivera Rosado LA, Zhang B (2013) Accumulation of autophagosomes in breast cancer cells induces TRAIL resistance through downregulation of surface expression of death receptors 4 and 5. Oncotarget 4:1349-1364

17. Diel P (2002) Tissue-specific estrogenic response and molecular mechanisms. Toxicol Lett 127:217-224

18. Ferlini C, Scambia G, Marone M, Distefano M, Gaggini C, Ferrandina G, Fattorossi A, Isola G, Benedetti Panici P, Mancuso S (1999) Tamoxifen induces oxidative stress and apoptosis in oestrogen receptor-negative human cancer cell lines. Br J Cancer 79:257-263. doi:10.1038/sj.bjc.6690042

19. Gamet-Payrastre L, Li P, Lumeau S, Cassar G, Dupont MA, Chevolleau S, Gasc N, Tulliez J, Terce F (2000) Sulforaphane, a naturally occurring isothiocyanate, induces cell cycle arrest and apoptosis in HT29 human colon cancer cells. Cancer Res 60:1426-1433

20. Gasper AV, Al-Janobi A, Smith JA, Bacon JR, Fortun P, Atherton C, Taylor MA, Hawkey CJ, Barrett DA, Mithen RF (2005) Glutathione $S$-transferase M1 polymorphism and metabolism of sulforaphane from standard and high-glucosinolate broccoli. Am J Clin Nutr 82:1283-1291

21. Gupta P, Kim B, Kim SH, Srivastava SK (2014) Molecular targets of isothiocyanates in cancer: recent advances. Mol Nutr Food Res 58:1685-1707. doi:10.1002/mnfr.201300684

22. Herman-Antosiewicz A, Johnson DE, Singh SV (2006) Sulforaphane causes autophagy to inhibit release of cytochrome $\mathrm{C}$ and apoptosis in human prostate cancer cells. Cancer Res 66:5828-5835. doi:10.1158/0008-5472.CAN-06-0139 
23. Hu R, Hebbar V, Kim BR, Chen C, Winnik B, Buckley B, Soteropoulos P, Tolias P, Hart RP, Kong AN (2004) In vivo pharmacokinetics and regulation of gene expression profiles by isothiocyanate sulforaphane in the rat. J Pharmacol Exp Ther 310:263-271. doi:10.1124/jpet.103.064261

24. Jackson SJ, Singletary KW (2004) Sulforaphane inhibits human MCF-7 mammary cancer cell mitotic progression and tubulin polymerization. J Nutr 134:2229-2236

25. Jakubikova J, Bao Y, Sedlak J (2005) Isothiocyanates induce cell cycle arrest, apoptosis and mitochondrial potential depolarization in HL-60 and multidrug-resistant cell lines. Anticancer Res 25:3375-3386

26. Jakubikova J, Sedlak J, Mithen R, Bao Y (2005) Role of PI3K/ Akt and MEK/ERK signaling pathways in sulforaphane- and erucin-induced phase II enzymes and MRP2 transcription, G2/M arrest and cell death in Caco-2 cells. Biochem Pharmacol 69:1543-1552. doi:10.1016/j.bcp.2005.03.015

27. Jemal A, Bray F, Center MM, Ferlay J, Ward E, Forman D (2011) Global cancer statistics. CA Cancer J Clin 61:69-90. doi:10.3322/caac. 20107

28. Jordan VC (2007) New insights into the metabolism of tamoxifen and its role in the treatment and prevention of breast cancer. Steroids 72:829-842. doi:10.1016/j.steroids.2007.07.009

29. Kabeya Y, Mizushima N, Ueno T, Yamamoto A, Kirisako T, Noda T, Kominami E, Ohsumi Y, Yoshimori T (2000) LC3, a mammalian homologue of yeast Apg8p, is localized in autophagosome membranes after processing. EMBO J 19:57205728. doi:10.1093/emboj/19.21.5720

30. Kallio A, Zheng A, Dahllund J, Heiskanen KM, Harkonen $P$ (2005) Role of mitochondria in tamoxifen-induced rapid death of MCF-7 breast cancer cells. Apoptosis 10:1395-1410. doi:10.1007/s10495-005-2137-z

31. Kanematsu S, Uehara N, Miki H, Yoshizawa K, Kawanaka A, Yuri T, Tsubura A (2010) Autophagy inhibition enhances sulforaphane-induced apoptosis in human breast cancer cells. Anticancer Res 30:3381-3390

32. Kassahun K, Davis M, Hu P, Martin B, Baillie T (1997) Biotransformation of the naturally occurring isothiocyanate sulforaphane in the rat: identification of phase I metabolites and glutathione conjugates. Chem Res Toxicol 10:1228-1233. doi:10.1021/tx970080t

33. Kelly RJ, Lopez-Chavez A, Citrin D, Janik JE, Morris JC (2011) Impacting tumor cell-fate by targeting the inhibitor of apoptosis protein survivin. Mol Cancer 10:35. doi:10.1186/1476-4598-10-35

34. Konecny G, Pauletti G, Pegram M, Untch M, Dandekar S, Aguilar Z, Wilson C, Rong HM, Bauerfeind I, Felber M, Wang HJ, Beryt M, Seshadri R, Hepp H, Slamon DJ (2003) Quantitative association between HER-2/neu and steroid hormone receptors in hormone receptor-positive primary breast cancer. J Natl Cancer Inst 95:142-153

35. Kuroiwa Y, Nishikawa A, Kitamura Y, Kanki K, Ishii Y, Umemura T, Hirose M (2006) Protective effects of benzyl isothiocyanate and sulforaphane but not resveratrol against initiation of pancreatic carcinogenesis in hamsters. Cancer Lett 241:275-280. doi:10.1016/j.canlet.2005.10.028

36. Lamy E, Mersch-Sundermann V (2009) MTBITC mediates cell cycle arrest and apoptosis induction in human HepG2 cells despite its rapid degradation kinetics in the in vitro model. Environ Mol Mutagen 50:190-200. doi:10.1002/em.20448

37. Lamy E, Schroder J, Paulus S, Brenk P, Stahl T, Mersch-Sundermann V (2008) Antigenotoxic properties of Eruca sativa (rocket plant), erucin and erysolin in human hepatoma (HepG2) cells towards benzo(a)pyrene and their mode of action. Food Chem Toxicol 46:2415-2421. doi:10.1016/j.fct.2008.03.022
38. Meeran SM, Patel SN, Li Y, Shukla S, Tollefsbol TO (2012) Bioactive dietary supplements reactivate ER expression in ER-negative breast cancer cells by active chromatin modifications. PLoS One 7:e37748. doi:10.1371/journal.pone.0037748

39. Melchini A, Costa C, Traka M, Miceli N, Mithen R, De Pasquale R, Trovato A (2009) Erucin, a new promising cancer chemopreventive agent from rocket salads, shows anti-proliferative activity on human lung carcinoma A549 cells. Food Chem Toxicol 47:1430-1436. doi:10.1016/j.fct.2009.03.024

40. Mi L, Wang X, Govind S, Hood BL, Veenstra TD, Conrads TP, Saha DT, Goldman R, Chung FL (2007) The role of protein binding in induction of apoptosis by phenethyl isothiocyanate and sulforaphane in human non-small lung cancer cells. Cancer Res 67:6409-6416. doi:10.1158/0008-5472.CAN-07-0340

41. Morales L, Neven P, Timmerman D, Christiaens MR, Vergote I, Van Limbergen E, Carbonez A, Van Huffel S, Ameye L, Paridaens R (2004) Acute effects of tamoxifen and third-generation aromatase inhibitors on menopausal symptoms of breast cancer patients. Anticancer Drugs 15:753-760

42. Nasu K, Takai N, Nishida M, Narahara H (2008) Tumorigenic effects of tamoxifen on the female genital tract. Clin Med Pathol $1: 17-34$

43. Nilsson S, Makela S, Treuter E, Tujague M, Thomsen J, Andersson G, Enmark E, Pettersson K, Warner M, Gustafsson JA (2001) Mechanisms of estrogen action. Physiol Rev 81:1535-1565

44. Pappa G, Lichtenberg M, Iori R, Barillari J, Bartsch H, Gerhauser C (2006) Comparison of growth inhibition profiles and mechanisms of apoptosis induction in human colon cancer cell lines by isothiocyanates and indoles from Brassicaceae. Mutat Res 599:76-87. doi:10.1016/j.mrfmmm.2006.01.007

45. Pawlik A, Wiczk A, Kaczynska A, Antosiewicz J, HermanAntosiewicz A (2013) Sulforaphane inhibits growth of phenotypically different breast cancer cells. Eur J Nutr 52:1949-1958. doi:10.1007/s00394-013-0499-5

46. Petrovski G, Zahuczky G, Majai G, Fesus L (2007) Phagocytosis of cells dying through autophagy evokes a pro-inflammatory response in macrophages. Autophagy 3:509-511

47. Peyrade F, Frenay M, Etienne MC, Ruch F, Guillemare C, Francois E, Namer M, Ferrero JM, Milano G (1996) Age-related difference in tamoxifen disposition. Clin Pharmacol Ther 59:401410. doi:10.1016/S0009-9236(96)90108-3

48. Pham NA, Jacobberger JW, Schimmer AD, Cao P, Gronda M, Hedley DW (2004) The dietary isothiocyanate sulforaphane targets pathways of apoptosis, cell cycle arrest, and oxidative stress in human pancreatic cancer cells and inhibits tumor growth in severe combined immunodeficient mice. Mol Cancer Ther 3:1239-1248

49. Pledgie-Tracy A, Sobolewski MD, Davidson NE (2007) Sulforaphane induces cell type-specific apoptosis in human breast cancer cell lines. Mol Cancer Ther 6:1013-1021. doi:10.1158/1535-7163.MCT-06-0494

50. Riggins RB, Thomas KS, Ta HQ, Wen J, Davis RJ, Schuh NR, Donelan SS, Owen KA, Gibson MA, Shupnik MA, Silva CM, Parsons SJ, Clarke R, Bouton AH (2006) Physical and functional interactions between Cas and c-Src induce tamoxifen resistance of breast cancer cells through pathways involving epidermal growth factor receptor and signal transducer and activator of transcription 5b. Cancer Res 66:7007-7015. doi:10.1158/00085472.CAN-05-3952

51. Ring A, Dowsett M (2004) Mechanisms of tamoxifen resistance. Endocr Relat Cancer 11:643-658. doi:10.1677/erc.1.00776

52. Samaddar JS, Gaddy VT, Duplantier J, Thandavan SP, Shah M, Smith MJ, Browning D, Rawson J, Smith SB, Barrett JT, Schoenlein PV (2008) A role for macroautophagy in protection against 4-hydroxytamoxifen-induced cell death and the 
development of antiestrogen resistance. Mol Cancer Ther 7:2977-2987. doi:10.1158/1535-7163.MCT-08-0447

53. Shen G, Xu C, Chen C, Hebbar V, Kong AN (2006) p53-independent G1 cell cycle arrest of human colon carcinoma cells HT-29 by sulforaphane is associated with induction of p21CIP1 and inhibition of expression of cyclin D1. Cancer Chemother Pharmacol 57:317-327. doi:10.1007/s00280-005-0050-3

54. Shou J, Massarweh S, Osborne CK, Wakeling AE, Ali S, Weiss H, Schiff R (2004) Mechanisms of tamoxifen resistance: increased estrogen receptor-HER2/neu cross-talk in ER/HER2positive breast cancer. J Natl Cancer Inst 96:926-935

55. Singh SV, Herman-Antosiewicz A, Singh AV, Lew KL, Srivastava SK, Kamath R, Brown KD, Zhang L, Baskaran R (2004) Sulforaphane-induced $\mathrm{G} 2 / \mathrm{M}$ phase cell cycle arrest involves checkpoint kinase 2-mediated phosphorylation of cell division cycle 25C. J Biol Chem 279:25813-25822. doi:10.1074/jbc. M313538200

56. Singh SV, Srivastava SK, Choi S, Lew KL, Antosiewicz J, Xiao D, Zeng Y, Watkins SC, Johnson CS, Trump DL, Lee YJ, Xiao H, Herman-Antosiewicz A (2005) Sulforaphane-induced cell death in human prostate cancer cells is initiated by reactive oxygen species. J Biol Chem 280:19911-19924. doi:10.1074/jbc. M412443200

57. Singh SV, Warin R, Xiao D, Powolny AA, Stan SD, Arlotti JA, Zeng Y, Hahm ER, Marynowski SW, Bommareddy A, Desai D, Amin S, Parise RA, Beumer JH, Chambers WH (2009) Sulforaphane inhibits prostate carcinogenesis and pulmonary metastasis in TRAMP mice in association with increased cytotoxicity of natural killer cells. Cancer Res 69:2117-2125. doi:10.1158/0008-5472.CAN-08-3502
58. Sunderland MC, Osborne CK (1991) Tamoxifen in premenopausal patients with metastatic breast cancer: a review. J Clin Oncol 9:1283-1297

59. Tang L, Zhang Y (2005) Mitochondria are the primary target in isothiocyanate-induced apoptosis in human bladder cancer cells. Mol Cancer Ther 4:1250-1259. doi:10.1158/1535-7163. MCT-05-0041

60. van Poppel G, Verhoeven DT, Verhagen H, Goldbohm RA (1999) Brassica vegetables and cancer prevention. Epidemiology and mechanisms. Adv Exp Med Biol 472:159-168

61. Vermeulen M, van den Berg R, Freidig AP, van Bladeren PJ, Vaes WH (2006) Association between consumption of cruciferous vegetables and condiments and excretion in urine of isothiocyanate mercapturic acids. J Agric Food Chem 54:5350-5358. doi:10.1021/jf060723n

62. Xiao D, Bommareddy A, Kim SH, Sehrawat A, Hahm ER, Singh SV (2012) Benzyl isothiocyanate causes FoxO1-mediated autophagic death in human breast cancer cells. PLoS One 7:e32597. doi:10.1371/journal.pone.0032597

63. Zaffaroni N, Daidone MG (2002) Survivin expression and resistance to anticancer treatments: perspectives for new therapeutic interventions. Drug Resist Updat 5:65-72

64. Zhang W, Couldwell WT, Song H, Takano T, Lin JH, Nedergaard M (2000) Tamoxifen-induced enhancement of calcium signaling in glioma and MCF-7 breast cancer cells. Cancer Res 60:5395-5400

65. Zhang Y, Kensler TW, Cho CG, Posner GH, Talalay P (1994) Anticarcinogenic activities of sulforaphane and structurally related synthetic norbornyl isothiocyanates. Proc Natl Acad Sci USA 91:3147-3150 